\title{
A Study of the Translation of Culture-Loaded Words in the Biography of Su Tungpo
}

\author{
Yaorui Zhuang \\ Fujian Normal University, Fuzhou, China \\ Email:1097972119@qq.com
}

How to cite this paper: Zhuang, Y.R. (2020) A Study of the Translation of Culture-Loaded Words in the Biography of Su Tungpo. Open Access Library Journal, 7: e6518.

https://doi.org/10.4236/oalib.1106518

Received: June 11, 2020

Accepted: July 4, 2020

Published: July 7, 2020

Copyright $\odot 2020$ by author(s) and Open Access Library Inc.

This work is licensed under the Creative Commons Attribution International License (CC BY 4.0).

http://creativecommons.org/licenses/by/4.0/

(c) (i) Open Access

\begin{abstract}
Su Tungpo (Su Shi) is an encyclopedic literary figure in the Song Dynasty in ancient China. He has open-minded attitude towards life and influences several generations. The Gay Genius: the life and time of Su Tungpo tells the story of Su. By introducing this Chinese literary genius to American readers, Lin Yutang, a famous Chinese writer and translator with four nominations of Nobel Prize, depicts the biography of Su with humor and skillful languages. His translation of the book made Su's works including his poetry, articles and philosophy of life spread overseas and gave a multidimensional portrayal of Su's life story. Evidently, culture-loaded words abound in the book. The translation of such words frequently makes translators exhausted and stranded. Focusing on the study of the translation of the culture-loaded words, this thesis intends to take Lin's The Gay Genius as an example to analyze the choices and the effects of different translation techniques due to different purposes under the guidance of domestication and foreignization.
\end{abstract}

\section{Subject Areas}

Linguistics

\section{Keywords}

Literary Translation of Biography, Culture-Loaded Words, Translation

Techniques, Domestication, Foreignization, Lin Yutang

\section{Introduction}

Lin Yutang, a world-renowned Chinese writer and translator of the 1900s, has profound influences on readers at home and abroad. He won four nominations of Nobel Prize. Lin Yutang wrote the biography of Su in 1944 in the English version to introduce the literary genius Su Tungpo to American readers. By trans- 
lating Su's achievements in literature and his life stories, Lin conveys his optimistic outlook to American readers and shares a vivid personality to the public.

With such academic status, the biography of Su written by Lin is worth discussing and exploring by our new generation. The study of the Gay Genius: the life and time of Sutungpo has academic significance in view of the culture-loaded words. On one hand, culture-loaded words provide details of culture-phenomenon as the medium of studying the differences between Chinese and Western culture. On the other hand, it demonstrates the value for the translation of Lin's works and biography written by him. Evidently, the study broadens insight for readers to better understand Su's life story.

Actually many scholars studied Lin at home and abroad. However, the researches on Lin's works are far from satisfactory.

Under this background, the study uses the translation strategies domestication and foreignization to analyze the translation of culture-loaded words in the Gay Genius: the life and time of Su Tungpo as theoretical support.

To examine the use of the two strategies above, it is essential for people to know the development of them in time line. From the 1870s to the 1970s, foreignization was once popular with translators. Ten years after the May 4th Movement, domestication took a dominant place in literary translation. In the last 20 years of the 20th century, Chinese translators inspired by western translation theories have reconsidered foreignization and domestication. As a result, foreignizating translation strategy has caught people's attention.

It is convinced that the translation of literature in the 21 st century will further develop foreignization. Indeed, the center of foreignizing translation is to interpret the "cross-culture words" in the original text, specifically, to carry cultural characteristics of the original work, the foreign language organization and the author's writing techniques and styles. At the same time, the strategy of foreignization translation has its own limitation. When it does few work to the text, domestication should be used.

The study is aimed to explore and reveal Lin's translation strategies adopted in the story of Su Tungpo in the hope of assisting readers in identifying the advantages and disadvantages of the translation methods adopted in the Gay Genius: the life and time of Su Tungpo.

As a biography labeled with Chinese culture, culture-loaded words are commonly seen in this book. To deal with such cross-culture phenomenon, the study analyses Lin's translation under the perspectives of foreignization and domestication as they are classical strategies bridging the gap between American and Chinese cultures. Through the analysis, the study is aimed to explore and reveal Lin's translation strategies adopted in the story of Su Tungpo in the hope of assisting readers in identifying the advantages and disadvantages of the translation strategies adopted in the Gay Genius: the life and time of Su Tungpo. The research also aims to guide translators on biography literature translation with characters of Chinese culture and provide inspiration to the global dissemina- 
tion of Chinese culture. Further, the interpretation of the translation may offer them deep understanding and motivate them to have in-depth analysis of Lin Yutang.

The paper is divided into four parts.

The first section is about the introduction, including the research background, the content of the research, the study methodology and significance of the research. The second is devoted to the literature review. It summarizes three respects, including studies on Lin Yutang at home and abroad, studies on the translation styles of Lin Yutang, studies on the Gay Genius: the life and time of Su Tungpo. The third is about studies of culture-loaded words, including definition, categories of culture-loaded words and the analysis of the translation of culture-loaded words. The fourth is conclusion.

\section{Literature Review}

\subsection{Studies on Lin Yutang at Home and Abroad}

In China, studies on Lin have three aspects. First, Lin explored himself about his lifespan experiences, views on education, views on feminism, views on culture in My Country and My People, Six Chapters of a Floating Life and Widow. So his notion of humour and philosophy of life is paid attention to. Second, academia focuses on features of writing and language skills. In the third respect, Lin is compared with other famous writers such as Xu Zhimo, who also studied abroad and held worldwide recognition. Scholars lay emphasis on the writers giving impact to Lin Yutang.

Lin Yutang is a world-famous translator and writer. He spent his whole life in translation and thus made significant contribution to the dissemination of Chinese culture. Taking Lin Yutang and Maxine Hong Kingston as two examples, Chen (1981: 61-70) [1] analyzes the historical origins and changes of The Golden Mountain, a metaphoric name for American dream, among the early Chinese immigrants to the US. It is argued that during a large amount of Chinese people rushed to California for seeking wealth of the last half of 18th century and zest for money changed to a pursuit of happiness as times passed by. This is a Chinese version of American Dream in successive generations of Chinese people, and which could be reflected from Lin and Kingston. A more recent study conducted by Li, J. and Li, C.B. (2016: 24-37) [2] also concluded that Lin's translation appears to be more concise and more skopos-driven. Lin is commented by Shi Jianwei (1994: 78-84) [3] as "Armed with both Chinese culture and Western bridging them by reviewing writings of the world". In his life, he translated and wrote more than 40 literature sharing household recognition. Among the literal works, he translated two biography literature which are the Biography of Wu Tze-tian and The Gay Genius in English version. The Gay Genius is his most-satisfied translation.

Actually, Lin has suffered criticizing from Chinese academia. 1990s was a turning point for Lin. 
Before that, Lin was criticized for his humor in literary production. When comes to thhhe 21st century, the books wrote by him spurs great enthusiasm of scholars at home and abroad. A lot of Chinese scholars like Fu Wenqi (2006: 102-105) [4] shifted emphasis from criticizing to translation studies, philosophy of life, genre studies, artistic. So far, the passion of studying Lin Yu has grown up in the prosperous age.

Under Lin's magic pen, his works are popular with American readers when they came out as bestsellers of western market in the 1940s. However when he is considered as a cosmopolitan intellectual of letters in the world, there are only a few studies on his translation because most of them focus on Lin's life, works, literary ideals and cultural spokesman.

Thanks to three relevant studies, Lin translation practice is paid attention to by Chinese scholars. Fang made careful research on image of women through Lin's My Country and My People, Confucius Met Nanzi and some other works and believe that these works encourage Chinese women to have voice heard [5]. In view of cultural internationalism, Lee, M.Y. (2009: 2) [6] thinks that Lin breaks restrictions of the symmetrical model and implemented reciprocal cultural exchange with the western world in perspex of cultural transmission, Qian, S.Q. (2010: 99) [7] points out that Lin promotes dissemination of Chinese culture as a renowned intellectual, calling him "American Success".

There is no doubt that Lin's contribution to cross-culture communication caught attention of the world. However, research on him about translating strategies and theories is given less attention by scholars.

\subsection{Studies on the Translation Styles of Lin Yutang}

Lin is the first bilingual writer in Chinese literary history as well as a translator. Together with his translation works, Lin has produced more than 20 books, which have been one of the hot topics for scholars to study.

On one hand, they analyzed Lin's works, particularly written in English by employing different artistic devices, which provides a multifaceted and prosperous study on his literary works. For example, Gao Wei and Liu Shicong (2001: 45-49) [8] studied the language features of Moment in Peking from a linguistic perspective. From Lin's writing and expression, they discussed that it is possible to transmit Chinese culture via English. In fact to write Chinese stories in English, writers are required to have abundant knowledge of China and English expertise. In their opinions, Lin can achieve it by spectacular language skills. Through an examination of Lin's representative works, Guo Maosheng (1996: 65) [9] made a conclusion that Lin's English has two features: one is "easiness, lucidity, simplicity and pithiness", and the other is "great senses of humor and genuineness". As the first writer who portrays China in a "devil tongue", Lin's skills in speaking the story of China to westerners have left implications to the writers and translators following. Recently, Shen Qinglin holds the view (2019: 74-83) [10] that Lin recognizes the "old Beijing" as a cultural icon for the Chi- 
nese civilization in the long stand on a paper published to study the image of Beijing under Lin's pen. Such cognition and identification can trace back to works like Moment in Peking, A Leaf in the Storm and Imperial Peking: Seven Centuries of China.

On the other hand, in the domestic scholars paid enormous attention to Lin's translation works. Over the past two decades, their studies have focused on Lin's translation theory and works from many perspectives. Some scholars studied his translation theory. Zhou Shibao held the view (2004: 107-110) [11] that Lin Yutang's translation theory gave out a brand-new perspective and theoretical foundation to modern Chinese translation theory. Lu Yang (2005: 19) [12] believed that Lin took "aesthetic equivalence" for ultimate criteria of translation. Today more researchers pay more attention to Lin Chinese-to-English translation. Ge Xiaoqin and Ji Zhengming (2001: 71-74) [13] advocated that Lin Yutang's living philosophy plays a decisive role in selecting the source texts for translating as well as translation strategies. When these scholars have more concerns on Lin's translation theory, some other translators or writers have focused on Lin's translation practices and strategies. Gao Wei (2001: 69-72) [8] remarked that it is possible for translation to communicate between different cultures according to Lin Yutang's solutions of using idiomatic expressions of the target language, retaining Chinese linguistic characteristics and changing syntactic structures. In 2005, Bian Jianhua (2005: 47-50) [14] pointed out that in Lin Yutang's English books there are many Chinese-English translations which are adaptations or retelling from the original Chinese texts. She presented a theoretical reconsideration of Lin Yutang's translation from the roles of an initiator and a translator in the light of the German functionalist approach. Also since the translation of Six Chapters of a Floating Life enjoys the most popularity from the translation studies, the strategies Lin employed in dealing with this Chinese classic are hotly debated. For example, Li Yuliang (2005: 79-83) [15] analyzed the strengths and flaws in Lin's translation; Wang Shaodi (2006: 33-37) [16] discussed the strategies in translating fuzzy language and suggested that with proper methods Lin left great imagination for readers; Dong Hui (2002: 11) [17] through a study on Lin's translation text concluded that his translation is "precise but accurate", "flow of expression" and "integrating language together with Culture". It is concluded that it is meaningful to take Lin's translation works as a guidance and reference for translation practices. Subsequently, studies on Lin Yutang's translation had an upsurge in China and the number of articles about Lin's translation works is increasing every year. In general, these studies are conducted from the perspective of cross-culture, aesthetics, intertextuality, translator's subjectivity and translation strategies.

\subsection{Studies on the Gay Genius: The Life and Time of Su Tungpo}

Su Tungpo is a famous poet in the Song Dynasty in ancient China. Interestingly, a world-renowned writer writes a biography for this historical celebrity. Through 
Lin's writing career, the Gay Genius is popular at home and abroad. Written in 1945 and published two years later, this biography made Su Tungpo a worldwide genius. However Lin's biography is mainly discussed and studies by scholars, the text of it is seldom researched.

Wan Jinping (2008) [18] believes that of all the biographies the Gay Genius is Lin Yutang's most satisfied one in his old age. Lin Yutang also admitted that the story of Su is his favorite work since it encouraged him to overcome his mental pain when facing trials and tribulations. In fact, when writing the biography, he found it hard to go through bankruptcy, and unfortunately followed. Hitting the low point in his life, he successfully completed the book with a spirit of optimism, and finally the publication of the new book by John Day Company was announced great success

After that, the famous Chinese genius Su Tungpo was well-known to the Americans and the protagonist $\mathrm{Su}$ has left a deep impression on readers even though they have never heard from him. The success may lie in the similarities shared by Lin Yutang and Su Tungpo. Two of them both lived in a turbulent age with similar social and political backgrounds. This made Su Tungpo's character image is reproduced in a vivid way under Lin's pen. According to a study, text-based study, Cheng Xia and Yang Yan (2011: 204-205) [19] analyzed the domesticating strategies employed by Lin in translating Su's poem. It is found out that Lin has used domestication on different levels of translation, and evidences were exemplified in writing style, lexical level, syntactic constructions and images of the poem.

Furthermore, the Gay Genius is discussed in academic level by comparing several Chinese versions. This version is well-performed in reproducing Lin's skillful language in shaping the image and personality of Su Tungpo. Among them, two versions are popular with readers: they are the version of Song Biyun and the version of Zhang Zhenyu. Both versions are examined and studied carefully in translation skills. Scholars focus on merits and deficiencies between the two Chinese versions.

\subsection{Studies on the Translation of Culture-Loaded Words}

\subsubsection{The Definition of Culture-Loaded Words}

Culture loaded words include words containing specific business in culture, showing a nation's lifestyle different from others its course of history. As a majority of Chinese culture, culture-loaded words can illustrate China's traditional culture and bridge cultural differences. Undoubtedly, translation of culture-loaded words will contribute to the effective export of our culture in global range.

\subsubsection{The Categories of Culture-Loaded Words}

Culture-loaded words represent the traditional culture of a country. Scholars hold different standards to classify them. According to E. A. Nida, culture-loaded words can be divided into five categories: ecological culture-loaded 
words, material culture-loaded words, social culture-loaded words, religious culture-loaded words and linguistic culture-loaded words.

\section{1) Ecological Culture-Loaded Words}

Ecological culture-loaded words reflect the climatic features, natural environment and geographical conditions in an area. People who live in different regions have unique expressions with regional characteristics.

\section{2) Material Culture-Loaded Words}

Material culture-loaded words include material products and technology invented by human beings derived from the development of society.

\section{3) Social Culture-Loaded Words}

Social culture-loaded words reflect social ideology, which refers to the system in form of social and economic factors in certain classes or groups.

4) Religious Culture-Loaded Words

Religious culture-loaded words reflect faith or belief centered in specific religion. Every country has its religion related with local traditional culture.

\section{5) Linguistic Culture-Loaded Words}

Linguistic culture-loaded words reflect phonetic meaning of language in level of language family. Different from English, Chinese language, especially idioms usually go with four-character structures.

\subsection{Studies on the Translation of the Culture-Loaded Words}

Chi Qingmei (2019: 94-95) [20] holds the view that the translation of culturally-loaded words faces two problems: the difficulty of balancing cultural differences and the reconciling thinking modes.

On the one hand, translators use the Chinese language as their mother tongue, and they are well-performed in understanding Chinese. However, when they do translation work, thinking in both Chinese and English becomes a must. To achieve the cultural equivalence, selecting accurate words to explain the culture-loaded words in the context of non-existence is a necessity for translators.

On the other hand, translators cannot rewrite the original text as they want. As translators, they shoulder the responsibility of being loyal to the original text. Therefore, keeping the balance of cultural differences has become the major difficulty for translators when rendering culture-loaded words, because Chinese people think in a different way compared with foreigners. Their distinguished ways of thinking come from the understanding of distance, location and national impression. While western people have a sense of belonging and solidarity with the motherland, the unique feelings among Chinese are often the spiritual and cultural connotations that the people of other ethics cannot fully understand even feel confused. In China, ethics is the most important spiritual bond connecting multiple nations. Therefore, when translators reproduce Chinese culture-loaded words with Chinese thinking, western readers will not be able to use interpretive translation and fail to understand in a coherent way because of differences in thinking. 


\section{Analysis of the Translation of Culture-Loaded Words in The Gay Genius}

The Gay Genius is a biography of Su Tungpo covering a wide range of his life, some of which are his reflections, and some of which are about the depression after his exile, and also his love and missing for his younger brother and his friends. In 1940s western readers rarely know any Chinese culture. Thus, such a biography of Su Tungpo, which contains lots of Su's poems against the Chinese Song Dynasty, was accepted by western readers, it should be attributed to Lin Yutang's successful application of translation strategies of domestication. Lawrence Venuti has given a further explanation to this as follows: "Admitting that translation can never be completely adequate to the foreign text, Schleiermacher allowed the translator to choose between a domesticating method, an ethnocentric reduction of the foreign text to target language cultural values, bringing the author back home, and a foreignizing method, an ethanol-deviant pressure on those values to register the linguistic and cultural difference of the foreign text, sending the reader abroad." (2004: 20) [21]

To make the foreign readers smoothly understand Chinese culture, Lin used a variety of different translation methods under the guidance of domestication to deal with culture-loaded words and poetry in this work for the purpose of maintaining the characteristics of Chinese language. The author summarizes the following five translation strategies.

\subsection{Transliteration}

Fang Mengzhi points out China Translation Dictionary that transliteration is a way of rewriting [22]. In other words, translators use a literal symbol to represent a literal symbol of another writing system. Under the situation of semantic non-equivalence, translators would find it hard to deal with texts from literal organization or in semantic level. To overcome this problem, transliteration is created and adopted on names, places and items in specific field. Usually, in translation from Chinese to English, Chinese names are usually translated in its Chinese spelling. Compared with Lin Yutang's English version and Zhang Zhenyu's Chinese version, the Chinese names like 苏东坡, 子由, 司马光, 王安 石 is translated as Su Tungpo, Tseyu, Szema Kuang and Wang Anshih. Places in China like 成都, 眉山, 密州 are translated into Chengtu, Meishan and Michow. What's more, culture-loaded words like 词, 赋, 阴, 阳, 衙门, 翰林 are translated as tse, fu, yin, yang, and hanlin followed the strategies of tuto remain the feature of Chinese characters. In conclusion, Culture-loaded words above are hard to be classified according to the five categories (material culture-loaded words, social culture-loaded words, religious culture-loaded words and linguistic culture-loaded words). To cope with these shortcomings in Nida's theory, transliteration becomes a necessity in the Gay Genius.

\subsection{Literal Translation}

Fang Mengzhi (2011: 105) [22] points out that transliteration is rewriting which 
uses one language symbol to reproduce another language symbol in its system. It focuses on maintaining the language organization and style of the original text including words, sentences even rhetorical devices. However, the target language should be easy-red and runs smoothly (1994: 90) [23]. A number of culture-loaded words adopt literal translation in the story of Su Tungpo, including 文忠公 (Literary Patriotic Duke), 三国 (the Three Kingdoms) and 赤壁 (Red Cliff) to achieve the simplicity and fluency of the translation instead of making extra interpretation. Proverbs and common sayings also can be translated literally. Here are examples of culture-loaded words from the Gay Genius as follows.

\section{Example 1}

中国有一句浐语, 就是说一个人如何, 要 “盖棺论定”。人生如梦, 一出 戏演得如何, 只有在幕落之时才可以下断语(Zhang, 2010: 16) [24]。

There is a current Chinese saying that final judgment upon a man is possible only when the cover is nailed on his coffin (Lin, 2019: 18) [25].

"Final judgment upon a man is possible only when the cover is nailed on his coffin" is a Chinese four-character proverb. This saying tells that one's success or failure can only be judged after his death. Here coffin (death) can be understood by understanding western culture as well as Chinese culture. Therefore, this literal translation bridges cultural differences by translating shared cultural images.

Example 2

他自称生性急躁, 遇有不殹心意之事, 便觉得 “如蝇在食, 吐之方快” 。 (Zhang, 2009: 原序 3)

He described himself as impatient in character and said that when there was something he disliked, he had to "spit it out like a fly found in one's food" (Lin, 1948: Preface X) [26].

"Spit it out like a fly found in one's food" is a Chinese proverb. It is used to describe a person who meets unhappy things and need to relax himself by forgetting about it. This description maintains the Chinese metaphor and vividly reproduces the laziness of Su Tungpo.

\section{Example 3}

人生到处知何似, 应似飞鸿踏雪泥。泥上偶然留指爪, 鸿飞那复计东西。 (Zhang, 2010: 69) [24]

To what can human life be likened? Perhaps to a wild goose's footprint on snow; the claws' imprint is accidentally left, But carefree, the bird flies east and west. (Lin, 2019: 140) [25]

Here Su uses metaphor device to describe the changeable affairs in one's life and encourage us to live an optimistic life and cherish the present like the wild goose. Lin's domestication of translation helps to keep Su original style in literal.

\section{Example 4}

我简直不由得要说苏东坡是火命, 因为他一生不是治水, 就是救旱, 不管 身在何处, 不是忧愁全城镇的用水, 就是担心运河和水井的开丵。说他是火 性并无不当, 因为他一生都是精力旺盛的, 简单说来, 他的气质, 他的生活, 就犹如跳动飞舞的火焰, 不管到何处, 都能给人生命温暖, 但同时也会把东 
西毁灭。过度热情(Zhang, 2010: 74) [24]。

I am almost tempted to say that the spirit of Su Tungpo represents the Element of Fire, for all his life he was fighting floods and drought and was always preoccupied with a city's water supply and with canal systems and drinking wells wherever he went. The symbol of fire is also appropriate simple words, his temperament and his whole life were like a leaping flame, giving life and warmth wherever it went and also destroying certain things on its way (Lin, 2019: 146) [25].

Fire, a religious culture-loaded word is regarded as five elements called wu xing in universe in ancient China. However here Lin's literal translation sees fire as character or spirit of Su. Under Lin's successful rewriting, Su's image of passion is interpreted and it explains why Su is so motivated to act in lively-hood of people.

\subsection{Transliteration \& Literal Translation}

When translating the material culture-loaded words such as historical sites and cultural relic or social culture-loaded words such as Dynasties, transliteration and literal translation can be used to make fluency and simplicity. For example, “北宋” is translated as Northern Sung dynasty, historical sites “颖州桥” and “巫 峡” is reproduced into The Stone Bridge of Ingchow and Wu Gorges. Other material items “后汉书”, “陇海铁路”, “三苏” and “元祐党人碑” are interpreted into Later Han History, Lunghai Railway, Three Sus and Yuanyu Partisans Tablet. The culture-loaded words usually have quantifiers, words of locality and words denoting time.

\subsection{Free Translation}

By analyzing the meaning in the original text, translators use free translation as a tool to roughly interpret by ignoring extra details to achieve fluency and simplicity. Actually, free translation emphasizes the main ideas based on the full understanding of texts, rather than literal translation. Some of the culture-loaded words are not adequate for transliteration and literal translation. When faced these difficulties, Lin applies free translation to interpreting Chinese language and makes satisfying results. Undoubtedly, Lin renders American readers to appreciate the biography of Su by foreignizing Chinese culture or simplifying Chinese expressions.

When talked about Water Margin (水汻传), Lin translated the book name as All Men Are Brothers. As one of China's four masterpieces, the book War Margin describes the stories of 108 brothers led by Song Jiang in Northern Song Dynasty. Lin's translation strategy makes readers grasp the theme of Water Margin. Moreover, 《诗经》is translated as the Book of Songs to show the content of the art work.

“重阳节” in Chinese corresponds to the ninth day of the ninth moon to implicit the time. “科举考试” is interpreted into a sentence, meaning imperial ex- 
amination is a system of selecting officials by examination in ancient China. Except for these above, Lin translates Su Tungpo's poetry in a free way. Here are some examples.

\section{Example 5}

去年东坡拾瓦砾，自种黄桑三百尺(Zhang, 2009: 181) [24]。

Last year I cleared the rubble on the Eastern Slope, and planted myself mulberries a hundred yards long (Lin, 1948: 189) [26].

Here “东坡” is not a name but a place. Su called himself “东坡居士” because he worked as a farmer in a field land and stayed far from politics. In this poetry, Lin wisely translates “东坡” into the Eastern Slope. Disregarding the translation of distance “尺” (yard), Lin's rewriting may be disloyal but makes Americans understand easily.

\section{Example 6}

苏东坡与弟弟苏辙正在这样熟读大量的文学经典之时，他父亲赶考铩羽而 归(Zhang, 2010: 41) [24]。

While Su Tungpo and his brother Tseyu were storing away this immense knowledge of literature and the classics, their father had failed at the examinations (Lin, 2019: 65) [25].

Here “铩羽而归” is a four-character proverb with metaphor device. The word means birds without feathers will fall to the ground. However, Lin deletes its literal implication but seeks to interpret it as failure of imperial examination to make readers understand the hardship of Su's father.

Example 7

这时两个青年的儿子, 在熟记经史, 在优秀的书法上, 恐怕已经胜过乃父 而雏凤清于老凤声了(Zhang, 2010: 42) [24]。

The probability is that the adolescent brothers had already outstripped their father, from exact memory of history to excellence of penmanship (Lin, 2019: 66) $[25]$.

Here “雏凤清于老凤凤声” is an excerpt of Chinese poetry. It means a baby phoenix sings more beautifully than an old one. However, the sentence shares the same meaning with “已经胜过乃父” and phoenix in western culture is related to demon. To avoid ambiguity, Lin chooses to translate the later and only uses one verb "outstrip" to praise the excellence of Su Tungpo and his brother.

\section{Example 8}

居丧守礼之下的一年又三个月的蛰居生活，是苏东坡青年时期最快乐的日 子(Zhang, 2010: 54) [24]。

The twenty-seven months of compulsory hibernation were the happy days of Su Tungpo's youth (Lin, 2019: 92) [25].

“蛰居” is a social culture-loaded word related to Chinese customs about funeral. Su Tungpo's mother passes away when Su Xun admitted by the imperial place. According to customs in Song Dynasty, together with two sons Sun Xun had to quit his job for a period during which he attended the ceremony of his wife and selected a site for family cemetery at Old Man's Spring. Here Lin uses 
metaphor "hibernation" to describe this custom.

\subsection{Transliteration \& Literal Translation and Free Translation with Notes}

In body text of the Gay Genius in Chinese version, the footnotes are not given by the translator (2009: 8). However, transliteration, literal translation and free translation with notes are provided by Lin to make readers more acceptable to the body.

Example 6

苏东坡不仅创造了他有名的 “墨竹” ，他也创造了中国的“文人画”(Zhang， 2009: 228)。

Su Tungpo not only originated his famous "ink bamboos", that is, paintings of bamboo in ink; he first created the name for a new style of Chinese painting, the style of "scholar man painting" (Shihjen Hua) (Lin, 1948: 240) [26].

Both "ink bamboo" and "scholar man painting" carry Chinese culture even though they are translated literally. But this translation still confuses western people because readers are unable to guess the meanings from these two words created by Lin. To avoid embarrassment, Lin adds apposition in "ink bamboo" to further explain that it is a painting of bamboo in ink. Meanwhile, he adds footnotes Shihjen Hua after "scholar man painting" to further explain it is created by Chinese scholars. Also in order to make translation more specific, Lin uses free translation to explicate the type of painting. In short, transliteration, free translation and footnotes are applied by Lin in the given part.

\section{Example 7}

那时有求婚的风俗, 京都中有未婚之女的富商都等待着考试出榜, 向新得 功名的未婚举子提亲。所以科举考试举行的季节, 也是婚姻大事进行得活跃 的季节(Zhang, 2010: 47) [24]。

At this time there was the custom of chuo-bun ("catch marriage"): rich merchants at the capital with unmarried daughters were on the lookout for the announcement of the results of the examinations, and were ready to negotiate financial settlements on successful bachelor candidates. The time of the civil service examinations was also the busy season of the matrimonial market (Lin, 2019: 83) [25].

In conclusion, the custom of chuo-bun may confuse western readers because the transliteration fails in reproducing Chinese spellings. To solve the problem, Lin gives notes to explicate it by free translation. However, western marriage custom is different from that in the Song Dynasty in ancient China. Therefore, Lin makes his translation complementary to the transliteration and free translation when they have little effect.

By analyzing the translation of culture-loaded words in the Gay Genius, we are able to summarize these strategies as transliteration, literal translation, notes and free translation. In some cases, utilizing multiple strategies is necessary. As a world-renowned translator, Lin has a solid bilingual foundation, cultural ac- 
complishment in China and US. Under his penmanship, the Gay Genius is one of the most popular biography translation in the world.

Even with such achievements, there are problems and highlights in Lin's translation. On one hand, one of the problems is that there was no unified standard for transliteration. Pinyin rules are not unified at home and abroad. Some of culture-loaded words fail to keep literal meaning. In order to preserve the originality of Chinese language, Lin chose to cope with texts by free translation as a way of domestication. But his translation is still open to readers. The modern era has seen great contributions Lin has made to disseminating and promoting Chinese culture to the world.

\section{Conclusions}

By analyzing Lin's choices under the guidance of domestication and foreignization, it can be found that in translation strategies of Lin, domestication plays a decisive role in the translation of culture-loaded words in The Gay Genius. And researches on Lin Yutang's translation under the guidance of these two strategies can provide more enlightenment to translators and promote the dissemination of Chinese culture.

However, from the stand of American readers, the literal translation is not suitable for Su's poetry translation even though literal translation is a wise choice to easily achieve domestication. But such domesticating approach should be criticized because it only seeks the equivalence in the linguistic forms and often loses the equivalence in content.

\section{Conflicts of Interest}

The author declares no conflicts of interest regarding the publication of this paper.

\section{References}

[1] Chen, L.C. (1981) Two Chinese Versions of the American Dream: The Golden Mountain in Lin Yutang and Maxine Hong Kingston. Multi-Ethnic Literature of the United States (MELUS), 8, 61-70. https://doi.org/10.2307/467389

[2] Li, J. and Li, C.B. (2016) A Comparative Analysis between Self-Translation and Conventional Translation of between Tears and Laughter from Gender Translation Perspective. Studies in Literature and Language, No. 6, 24-37.

[3] 施建伟 (1994) 近十年来林语堂作品在大陆的流传与研究. 同济大学学报(人文 社会科学版), No. 2, 78-84.

[4] 傅文奇 (2006) 近十年来林语堂研究的统计与分析. 福建论坛(人文社会科学版), No. 5, 102-105.

[5] Fang, L. (2010) The Afterlife of Six Chapters of a Floating Life: Three English Translations of Fu Sheng Liu Ji. Translation Review, 80, 25-52. https://doi.org/10.1080/07374836.2010.10524028

[6] Lee, M.Y. (2009) The Intellectual Origins of Lin Yutang's Cultural Internationalism 1928-1938. University of Maryland, College Park. 
[7] Qian, S.Q. (2010) Representing China: Lin Yutang vs. American “China Hands” in the1940s. Journal of American-East Asian Relations, 17, 99-117. https://doi.org/10.1163/187656110X528974

[8] 高嵬, 刘士䏲 (2001) 从 Moment in Peking 的写作对汉译英的启示看英语语言之 于汉语文化的表现力. 外语教学, No. 4, 45-49.

[9] 郭茂生 (1996) 谈林语堂的英语语言特色. 外国语(上海外国语大学学报), No. 3, 65-69.

[10] 沈庆利 (2019) 以北京想象中国一一论林语堂的北京书写. 北京师范大学学报 (社会科学版), No. 1, 74-83.

[11] 周仕宝 (2004) 林语堂的翻译观. 外语学刊, No. 2, 107-110.

[12] 陆洋 (2005) 论“美译”一一林语堂翻译研究. 中国翻译, No. 5, 49-55.

[13] 葛校琴, 季正明 (2001) 人生态度取向与翻译的选择及策略一谈林语堂《浮生六 记》的翻译. 解放军外国语学院学报, 24, 71-74.

[14] 市建华 (2005) 对林语堂“文化变译”的再思考. 上海翻译, No. 1, 47-50.

[15] 李玉良 (2005) 林译《浮生六记》的得与失. 山东外语教学, No. 6, 79-83.

[16] 王少娣 (2006) 试论模糊语言在翻译中的审美再现: 从林语堂之英译《浮生六记》 谈起. 天津外国语学院学报, No. 3, 33-37.

[17] 董晖 (2002) 老到圆熟, 出神入化: 林语堂《浮生六记》英译本赏析. 西安外国语 学院学报, No. 3, 11-15.

[18] 万平近 (2008) 林语堂评传. 上海远东出版社, 上海.

[19] 程霞, 杨艳 (2011) 林语堂的《苏东坡传》中古诗词翻译的归化策略. 赤峰学院 学报(汉文哲学社会科学版), 32, 204-205.

[20] 茌庆梅 (2019) 汉语文化负载词及其英译策略探究. 山东农业工程学院学报, 36, 94-95.

[21] Venuti, L. (2004) The Translator's Invisibility. Shanghai Foreign Language Education Press, Shanghai.

[22] 方梦之 (2011) 中国译学大辞典. 上海外语教育出版社, 上海.

[23] 范仲英 (1994) 实用翻译教程. 外语教学与研究出版社, 北京, 90-91.

[24] 林语堂 (2010) 苏东坡传. 张振玉, 译, 陕西师范大学出版社, 西安.

[25] 林语堂 (2019) 《苏东坡传》双语版. 张振玉, 译, 湖南文苑出版社, 长沙.

[26] Lin, Y.T. (1948) The Gay Genius: The Life and Times of SuTungpo. William Heinemann Ltd., London. 